\title{
PSA Velocity
}

National Cancer Institute

\section{Source}

National Cancer Institute. PSA Velocity. NCI Thesaurus. Code C20119.

A type of PSA assay which compares changes in PSA levels over time. A sharp rise in the PSA level raises the suspicion of cancer. (from Cancer Information Service) 